\title{
Proaktive underviserværktøjer \\ - en støtte for proaktive undervisere i e-læringsmiljøer
}

\author{
Rikke Ørngreen \\ Adjunkt \\ HCI forskningsgruppen \\ Institut for Informatik \\ CBS \\ orngreen@cbs.dk \\ http://asp.cbs.dk/hci
}
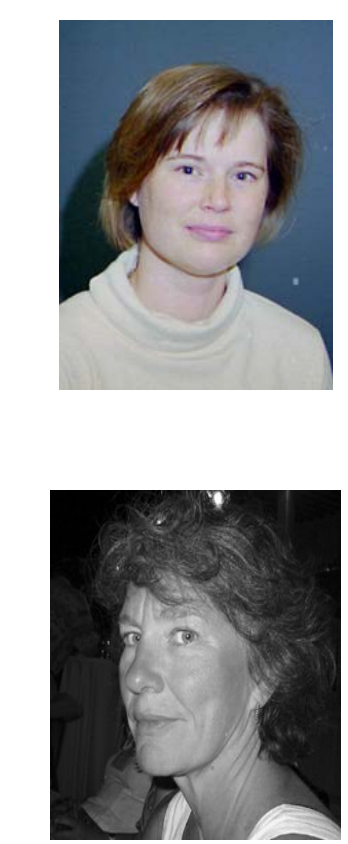

\author{
Karin Levinsen \\ Cand. Mag. \\ HCI forskningsgruppen \\ Institut for Informatik \\ CBS \\ kle.inf@cbs.dk \\ http://asp.cbs.dk/hci
}

Rikke Ørngreen har undervisningserfaring fra CBS (datalogi- og økonomi-retningen og den internationale CEMS-linje), samt IT-U (e-business-linjen) og MIL Master i IKT og læring). Primær forskningsinteresse er inden for tilrettelæggelse, design og brug af videnssystemer i et HCI-perspektiv. Dvs. informations- og kommunikationssystemer rangerende fra informationsportaler til mere komplekse kollaborative e-læringssystemer. Har praksiserfaring med HCI og interaktionsdesign, multimedieudvikling, samt en speciel interesse for case-baseret udvikling, undervisning og lering.

Karin Levinsen, der er i den sidste skrivefase i sit Ph.D. forløb, har mangeårig erfaring inden for IKT, kommunikation og lcering. Dels som professionel pcedagogisk udvikler af multimedieproduktioner og IKT-baserede undervisningskoncepter i bl.a. Courseware A/S. Dels som underviser på RUC ved Kommunikationsuddannelsen og Master i Computermediated Communication, og nu også på CBS (datalogi- og økonomi-retningen) og IT-U (DKM- og Ebussiness- linjerne. Hun arbejder på en ph.d.-afhandling om online-undervisning på universitetsniveau.

\section{Introduktion}

Denne artikel tager udgangspunkt i to case-studier - case-baseret og kollaborativ e-læring der repræsenterer to forskellige pædagogiske fremgangsmåder samt deres tilhørende aktiviteter, der fordi de specielt er designet til eller tilpasset et online-læringsmiljø, med Salmons begreb, benævnes e-tivities (Salmon 2002). Den første undersøgelse belyser spørgsmål, der er dukket op under udviklingen af CaseMaker, et online-miljø for case-baseret e-læring. Det andet studie præsenterer resultater fra uddannelsen Master i IKT og Læring (MIL), der udbydes som en blanding af e-læring og tilstedeværelsesundervisning. I begge case-studier anvendes en samarbejdsorienteret, kollaborativ pædagogik, som derfor udgør den fælles referenceramme for case-studierne. På denne baggrund har vi fundet, at undervisere i løbet af IKTstøttede undervisningsforløb, kan møde en række problemer, når de ønsker at følge deres stu- 
derendes progression og få fornemmelse for måden hvorpå de udvikler et praksisfællesskab (Wenger 1998) i løbet af et kursus.

I de to undersøgelser er underviser/student-relationen således, at undervisere optræder i rollen som coaches, mens de studerende har ansvar for deres egen læring. Coaching er en kombination af en proaktiv handlestrategi (Ackoff 1976; Hildebrandt 1997) og en indlevelses- og spørgemetode (Stelter 2002), hvilket indebærer at underviseren for at kunne stille de "rigtige spørgsmål” til de studerende, løbende må have føling med, hvor de studerende er i deres læringsproces. Med "rigtige” spørgsmål menes spørgsmål, der fungerer som katalysator for en proces, hvor de studerendes egne ressourcer udfolder sig - dvs. spørsgmål der får de studerende til at fokusere deres egen opfattelse, være kritiske over for deres subjektive fortolkninger og forholde sig til egne strategier og måder at løse en opgave på (Stelter 2002 : 26) . Denne form for igangsættende coaching adskiller sig fra vejledning og rådgivning, hvor underviseren i højere grad fortæller de studerende, hvad de bør overveje, og i hvilken retning de bør gå, og fra den kontrol der kendes fra klassiske undervisercentrerede og instruerende undervisningsformer.

Grundlaget for underviserens beslutninger om at justere i læringsprocesser og valg af måder at coache på, er en kombination af flere forhold: Dels opmærksomhed i situationer, hvor det er muligt at iagttage de studerendes interaktion. Dels viden og indsigt i at fortolke fremspirende tendenser i de studerendes læreproces. Coaching som metode er proaktiv fordi den forudsætter en viden hos coachen, der er i bevægelse sammen med processen, og coaching er indgribende i processen, fordi coachens spørgsmål fungerer som proceskatalysator. Dette indebærer, at hvis undervisere skal kunne udføre en rimelig coachning, må de kunne tilegne sig en viden om de studerendes fremspirende kollaborative interaktion, progression og problemer. Hvordan kan grundlaget for en sådan nødvendig viden etableres i e-lærings miljøer?

\section{Reaktiv og Proaktiv Undervisning}

På grund af forskellig praksis agerer undervisere, der anvender instruktiv pædagogik, reaktivt, mens undervisere, der anvender kollaborativ pædagogik, agerer proaktivt. Inden for klassisk instruktionspædagogik instruerer undervisere de studerende ved at stille dem opgaver (Reigeluth 1999), som de studerende besvarer og bliver bedømt for. I kollaborativ læring må underviserne kunne opspore og følge tendenser i kommunikationsprocesser og gruppearbejde for løbende at kunne opretholde et grundlag for at tage proaktive beslutninger om, hvorledes de skal coache og vejlede i løbet af et kursus (Dirckinck-Holmfeld 2002; Fjuk \& Ludvigsen 2001; Sorensen 2003; Sorensen \& Takle 2003). Årsagen er, at mens de studerende kommunikerer og arbejder sammen, udvikler de under processen mere eller mindre passende normer og holdninger til kommunikation og social adfærd inden for det praksisfællesskab, der er under opbygning (Levinsen \& Orngreen 2003; Wenger 1998).

Inden for konstruktivistisk orienterede pædagogikker benyttes betegnelsen proaktion oftest i forbindelse med en studenterrelateret tilgang, hvor de studerende med brug af procesværktøjer som f. eks. personlige- og gruppeportfolios, kan være proaktive i forhold til deres egne læreprocesser. Derimod er der ikke publiseret meget om underviseres muligheder for at handle proaktivt som coaches, mens de støtter de studerendes proces. Litteraturen i dette felt fokuserer på undervisernes handlemuligheder i korte tidshorisonter, og på hvordan underviseren rent faktisk kommunikerer, medierer og sammenholder indlæg i skrevne diskussionsfora (e.g. Laurillard 2002, Salmon 2002, Levinsen 2003, Sorensen 2003).

I en undersøgelse baseret på kandidatstuderendes arbejde har Murphy, Epps og Harvell (1999) identificeret faktorer, der er afgørende for at få kollaborative IKT-miljøer til at fungere (se tabel 1). I modsætning til instruktiv pædagogik kan vi se, at disse faktorer peger på underviserens bevidsthed om, samt løbende interaktion for at støtte de studerendes progression. 
Faktorerne fokuserer således på proaktion og coachende indgriben i processen, ikke kun på handlinger før (planlæggende) og efter (evaluering) processen. Men selvom den proaktive coach-rolle omfatter det at følge progressionen som en forudsætning for proaktion, er der ingen forslag til, hvordan man kan give undervisere indsigt i igangværende processer i et IKT miljø.

\begin{tabular}{|l|l|}
\hline Proaktive underviserroller & Proaktive studenterroller \\
\hline Etablerer retningslinier & Får kendskab til de andre gruppemedlemmer \\
\hline $\begin{array}{l}\text { Definerer målsætning og tidshorisont for } \\
\text { gruppeprojekter }\end{array}$ & Etablerer gruppekontakt \\
\hline $\begin{array}{l}\text { Overvåger grupperne og de individuelle med- } \\
\text { lemmers udvikling }\end{array}$ & Fastsætter gruppens mål og formål \\
\hline Faciliterer interaktion og samarbejde & Identificerer gruppemedlemmernes roller \\
\hline Giver rådgivning og vejledning & Opretholder gruppedynamik \\
\cline { 2 - 2 } & Finder problemer \\
\cline { 2 - 2 } & Tilbagemelding om forløb til underviser \\
\hline
\end{tabular}

Tabel 1. Underviseres og studerendes roller i proaktiv gruppedynamik, kilde: Murphy, K.L., Epps, M:L., \& Harvell, T.J., 1999, tabel 1 (oversat)

Selvom litteraturen inden for kollaborativ og konstruktivistisk læring hævder, at en undervisers hovedopgave i disse aktiviteter er at facilitere processen, finder vi, at meget lidt bliver sagt om, hvad der kan gøres for at give underviseren et grundlag for at udføre denne opgave i e-læringsmiljøer.

\section{Underviserværktøjer i e-læring idag}

Hvis vi ser på hvilke muligheder underviseren har for at praktisere coaching i IKT-miljøer, er der heller ikke stor fokus på støtteværktøjer til proaktive undervisere. En oversigt over diverse almindelige learning management systems (LMS) viser, at de fleste af dem har mange fælles træk (Orngreen, Nielsen \& Levinsen 2004). Ud fra en opfattelse af at uddannelse er en proces, støtter disse fælles træk konstruktionen af læringsmiljøet og den faktiske udførelse af undervisningen, og der er intet i de fælles træk, der begrænser valget af pædagogik. Dog er værktøjerne til at undersøge og evaluere den løbende læreproces begrænset til instruktionspædagogik. De fleste LMS'er har en omfattende værktøjskasse til at konstruere automatiserede prøver: dvs. variationer over temaet "underviseren spørger - studenten svarer". Der eksisterer værktøjer til at overvåge studerende i form af rapporter om den individuelle studerendes adfærd. Rapporterne omfatter en log af de studerendes aktiviteter i udvalgte områder af LMS'en sammen med eksakte klokkeslæt og datoer. Rapporter om de studerendes indsats for at opfylde angivne krav samt opsummeringer af studerendes udførelse af opgaver er også tilgængelige. Disse rapporter peger mere på underviserens rolle som instruktør end som coach.

Således formidler e-læringsmiljøer idag overblik over bestemte typer processer ved at give mulighed for alternative visninger af indholdet i diskussionsfora og de studerendes præstationer i form af deres bevægelser i diverse debatfora samt målbare testresultater (dvs. antal af tråde i et diskussionsforum mv). Disse måder at anskue læringsprocesser på, ligger inden for instruktionspædagogikken. I beskrivelserne af forskellige LMS'er betegnes disse værktøjer da også som "underviserens værktøjer til design og kontrol af undervisningsforløb” (Levinsen 2005). Dvs. at en underviser kan se, om en person har eller ikke har indsendt materiale på den måde, det er påbudt i et bestemt diskussionsforum. Denne form for indblik er imidlertid ikke tilstrækkeligt, når det gælder læring baseret på samarbejde, fordi processerne her udvikler sig uforudsigeligt, og deltagerne har en tendens til at producere store mængder af indlæg (som 
påvist senere i de to case-studier). Denne uforudsigelighed gør det vanskeligt at sætte sin lid til intelligente underviserværktøjer, og den store mængde indlæg gør det vanskeligt og tidskrævende at opnå viden om og overblik over de tendenser, der begynder at tegne sig. Disse begrænsninger efterlader coach-undervisere, der anvender kollaborativ pædagogik, uden værktøjer til etablering af et proaktivt beslutningsgrundlag.

Det sidste område, vi har undersøgt for at identificere interesseområder i forbindelse med støtteværktøjer til proaktive undervisere, er en deltagerbaseret tilgang til design. Claroline er et 'open source' "kollaborativt læringsmiljø, der gør det muligt for undervisere eller uddannelsesinstitutioner at etablere og administrere kurser ved hjælp af web’en”, hvor en gruppe af designere rundt om i verden bidrager til dets udvikling." (Claroline 2004). Claroline er udviklet i 'open source' -ånden, hvilket betyder, at læringsmiljøet er under stadig udvikling og hver aften opdateres med den seneste åbne kildekode (men der findes dog også pakkeversioner). Det betyder, at Claroline forandrer sig hele tiden i overensstemmelse med brugernes ønsker, og udviklingen udføres i forskellige geografiske regioner af ekspertbrugere og udviklere i elæring.

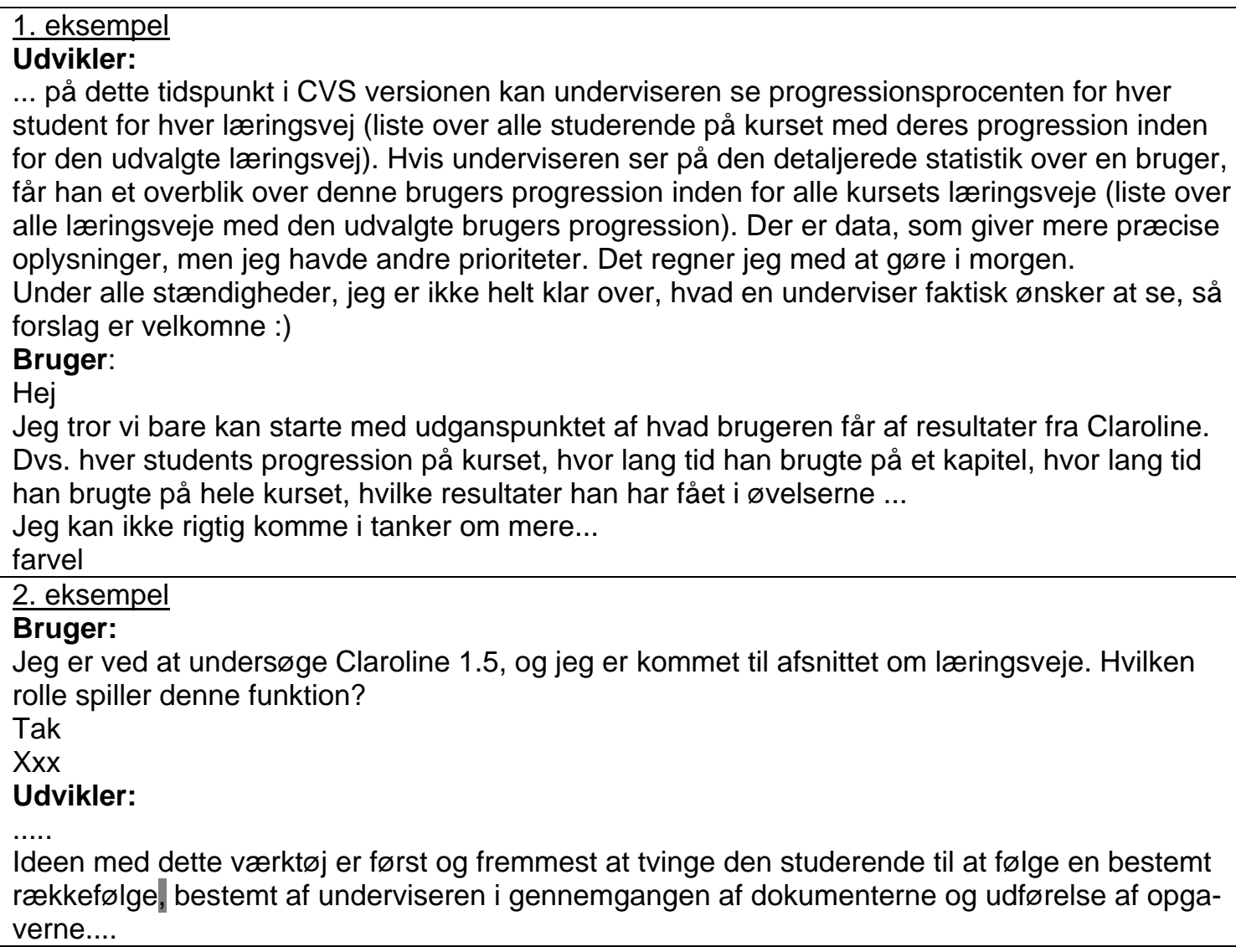

Ideen med dette værktøj er først og fremmest at tvinge den studerende til at følge en bestemt rækkefølge, bestemt af underviseren i gennemgangen af dokumenterne og udførelse af opgaverne....

Tabel 2. Uddrag fra to diskussioner i maj 2004. (Tekst fremhevet af forfatterne samt oversat fra engelsk og fransk fra hhv. http://www.claroline.net/forum/viewtopic.php?t=2280 og http://www.claroline.net/forum/viewtopic.php?t=2300)

Uddragene i tabel 2 er fra Clarolines debatforum om udvikling og understreger yderligere vores argument, at selv ikke designere og brugere fokuserer på de ovenfor nævnte emner, når de arbejder på en mere brugerorienteret måde. I denne brugerorienterede udviklingsgruppe er undervisernes værktøjer til overvågning af processer reduceret til ren planlægning, forhindring eller begrænsning af uventede tendenser og kontrol af studerendes adfærd (tabel 2).

Som allerede nævnt har mange forskere beskæftiget sig med dette emne, især med fokus på organisering af deltagere i samarbejdskonstellationer og på oplæring i kommunikative og sociale færdigheder inden for online-miljøer. Med undtagelse af denne forskning, har kun få 
undersøgelser beskæftiget sig direkte med støtte til proaktion i undervisningen. Vi har eksperimenteret med proaktive pædagogiske metoder og identificeret områder, hvor der er brug for proaktive værktøjer (Levinsen \& Ørngreen 2003). Inden for feltet Intelligente Undervisningssystemer har Reffay og Chanier eksperimenteret med automatiserede værktøjer, inspireret af Social Network Analysis (Reffay og Chanier 2003). I Social Network Analysis ses på hvilke relationer der er mellem aktører i en proces - bl. a.. relationernes art, intensitet og udstrækning i tid og rum (Wasserman \& Faust1994). Med Reffays og Chaniers værktøjer er det nu muligt at identificere forskellige aspekter ved gruppeadfærd og individuel marginalisering (Reffay og Chanier 2003). Problemet med de automatiserede værktøjer er, at fordi kollaborative samarbejdsforløb kan og ofte vil udvikle sig uforudsigeligt, så findes der ikke nogen forudberegnet eller teoretisk defineret gruppeadfærd, som den observerede gruppeadfærd kan måles op imod.

På grundlag af vores litteraturstudier er vi derfor kommet til den konklusion, at skønt forfattere påpeger behovet for, at coach-undervisere underviser deres studerende proaktivt, så findes der ingen konkrete henvisninger til, hvordan de rent faktisk skal gøre dette online.

\section{De to case-studier}

I de følgende underafsnit vil vi præsentere de to case-studier og de spørgsmål og dilemmaer, som coach-undervisere må tage stilling til ved gennemførelsen af kollaborativ e-læring.

\section{Casebaseret læring og CaseMaker projektet}

CaseMaker er et online-miljø for case-baseret e-læring, som er under udvikling af en af forfatterne på Institut for Informatik sammen med CBS Learning Lab. Det har bl.a. til formål at anspore og støtte de studerende til at udføre af case-analyse på et højt niveau, hvilket fremmer læreprocessen i casen. Applikationen støtter også undervisere i at udvikle cases og facilitere case-læring. Imidlertid skaber case-analysens format og den traditionelle brug af cases nogle interessante dilemmaer, når det kommer til at give case undervisere et overblik over de studerendes proces.

Case-læring ansporer de studerende til at tilegne sig viden om praksis og forbedre deres forståelse af ustrukturerede og komplekse situationer. Case-læring involverer studerende aktivt i deres egen læreproces gennem samarbejde og diskussioner om casen med medstuderende, hvilket bringer dialogen op på et højere niveau (Heath 1998; Mauffette-Leenders, Erskine \& Leenders 1997). Empirisk forskning og litteraturstudier viser imidlertid, at undervisere ofte har vanskeligt ved at skabe en teoretisk ramme om casen. De har svært ved at motivere de studerende til at analysere casen ved hjælp af modeller eller diskutere, hvordan en teori kan anvendes i en given situation. Resultatet er ofte, at de studerende trækker på personlige erfaringer og undlader kritisk refleksion og kun deltager i diskussioner ud fra et kendskab til og forståelse af indholdet, i stedet for på grundlag af analyse, refleksion og vurdering af indholdet i relation til fagområdet (Argyris 1980; Ørngreen 2002; Williams 1992).

I designforslagene til CaseMaker er vi blevet inspireret af software-programmer til kvalitativ dataanalyse. Hensigten er at udvikle værktøjer, som kan støtte de studerende i at analysere cases med udgangspunkt i kritisk refleksion og et aktivt samarbejde. Den første version af CaseMaker vil sætte de studerende i stand til at undersøge case-materialet og tilføje tema, nøgleord og kommentarer til hvert materialesæt, hvad enten det drejer sig om tekst, billede, lyd eller filmelement. Undervisere kan på forhånd vælge temaer, som de studerende kan analysere efter, eller de studerende kan vælge at indordne deres analyse løbende i forskellige temaer. For yderligere at forbedre samarbejdet holder CaseMaker rede på. hvem (i en gruppe af studerende) der definerede hvilket tema eller nøgleord og skrev hvilke kommentarer hvor og hvornår. Mens de studerende koder materialet, kan de vælge at se den løbende analyse og 
resultatet af denne gennem forskellige former for filtrering. Dvs. at en undersøgelse af alle nøgleordene knyttet til et specielt materiale eller materialet og kommentarerne knyttet til det samme nøgleord, vil hjælpe de studerende med at reflektere over analysen og nå frem til (ved at skrive eller tage noter) fortolkninger og konklusioner til den samlede case-analyse. Herunder er givet en kort beskrivende eksemplificering af denne funktionalitet, se tabel 3. (For yderligere oplysninger om CaseMaker programmets generelle funktioner, se Orngreen 2004).

Et eksempel: en studerende som lige er begyndt på et "design af websites"-kursus ser på et web-sted, tre brugerinterviews og et interview med en designer, som underviseren har lagt som materiale i en case.

I analysen af datamaterialet til casen - her web-stedet -, bliver den studerende opmærksom på en bestemt problemstilling, der blev gennemgået ved sidste forelæsning. Den studerende tilføjer derfor nøgleordet: "observation" under temaet "brugervenlighed". Derefter skriver han følgende kommentar til nøgleordet: "for at se om et site er brugervenligt kunne man observere brugerne, når de bruger sitet i deres daglige omgivelser".

Den studerende ser nu videre i et af brugerinterviewene og husker nu, at de på holdet gennemgik en bestemt teori i starten af semestret, som måske kan anvendes. Navnet på teorien, sætter han som nøgleord under temaet "Teori", sammen med en længere beskrivelse.

Senere synes den studerende, at det er væsentligt ikke kun at tænke i brugervenlighed men også udviklingstid, derfor tilføjes et nyt tema kaldet: "udviklingstid". Den studerende sætter en række argumenter (som flere forskellige nøgleord og beskrivelser) ind til det nye tema: "udviklingstid".

I løbet af og efter endt case-analyse skifter den studerende mellem indskrivning af egen analyse og et skærmbillede, hvor de øvrige gruppemedlemmers nøgleord og kommentarer kan ses. Ofte inspirer de øvrige gruppemedlemmers analyse den studerende ti,l at foretage nyt eller supplerende analysearbejde.

\section{Tabel 3. et eksempel på brug af tema, nøgleord og kommentarer i CaseMaker}

Med en relativ lille case og med et lille antal studerende er det overkommenligt manuelt at danne sig et overblik over, hvilke tendenser der er under udvikling, samt hvad der sker i øjeblikket - dvs. den retning de studerendes analyse bevæger sig i, og hvordan de reflekterer i læreprocessen. Både de studerende og underviserne kan skimme gennem indlæggene, sorteret efter dato, person, osv. og se, hvorledes perspektiver over tid har ændret sig eller er ved at ændre sig. Men mængden af data vokser meget hurtigt, når vi ser på den samlede case-analyse samt antallet af nøgleord og kommentarer. På et hold med ca. 50 personer og én case med 10 stykker materiale kan underviseren få 500 kommentarer, hvis hver af de studerende skriver blot én kommentar til hvert materiale i deres analyse, uden at tilføje løbende eller endelige fortolkninger. I virkeligheden vil de studerende sikkert skrive langt mere end én kommentar og bruge større eller flere cases på et kursus.

\section{Kollaborative dialogbaserede og produktorienterede pædagogikker}

Masteruddannelsen i IKT og Læring (MIL, http://www.hum.aau.dk/mil) er en to-årig uddannelse, afviklet som en blanding af online-forløb og tilstedeværelsesseminarer. MIL er baseret på variationer inden for den konstruktivistiske pædagogik (Dirckinck-Holmfeld 2002).

I 2002 blev et hold på 53 voksenstuderende på MIL observeret i første semester (Levinsen 2004). Det første semester begyndte med en online-introduktion til LMS, og de studerende mødes på to weekendseminarer. På det først seminar blev holdet opdelt i 10 arbejdsgrupper. Hver gruppe fik tildelt et privat grupperum i MIL's LMS, Virtual-U (VU). I løbet af semestret deltog grupperne i henholdsvis modul M1 og M2, som er to parallelle kurser.

M1's fokus er læringsteori og kollaborativ online-læring. Underviseren organiserer de studerende i forskellige samarbejdskonstellationer med hensyn til roller og opgaver, efter hvilken 
pensum diskuteres (Sorensen 2002). De studerende bliver evalueret på mængden og kvaliteten af de enkelte indlæg, de bidrager med i diskussionerne, der foregår i M1's offentlige diskussionsforum (Sorensen \& Takle 2003) M2’s fokus er på menneske-computer interaktion og visuelt design af interaktive læringsapplikationer. M2 underviserne forventer, at de studerende selv organiserer videndeling i det offentlige M2 diskussionsforum, mens de arbejder på deres opgaver i det private grupperum. Underviserne har faste vejledningstider. De studerende bliver evalueret på baggrund af deres skriftlige opgaver ved slutningen af hvert delkursus på modulet. Den afsluttende opgave består i at designe en brugergrænseflade til en elæringsapplikation og udføre en brugertest.

I hele semestret kom der 2.244 indlæg til det offentlige diskussionsforum: 1.917 fra M1 og 327 fra M2. Når man tager i betragtning, at det faglige indhold, målsætningen og bedømmelseskriterierne er meget forskellige på de to moduler, må antallet af indlæg nødvendigvis også være forskelligt. Men det store antal indlæg viser ikke, om det overordnede formål med MIL er opfyldt, nemlig at fremme kollaborativ læring og vidensdeling blandt de studerende (MIL Modulkatalog 2002). Brugen af VU’s statistiske værktøjer, dvs. antal af indlæg fra alle eller en enkelt studerende, giver heller ikke underviserne (eller de studerende for den sags skyld) oplysninger om, hvordan de studerende kommunikerer, om de samarbejder på den tilsigtede måde eller om interessante kommunikationsmønstre dukker frem, osv.. VU og andre LMS'er har ingen værktøjer til den slags analyser af kurserne, og antallet af indlæg er alt for stort til, at underviserne kan analysere dem manuelt.

\section{Proaktive underviserværktøjer}

\section{- specifikke forslag og generelle betragtninger}

I dette afsnit vil vi fokusere på og beskrive de forskellige perspektiver på indlæg, som de proaktive underviserværktøjer skal kunne generere for at give coach-underviseren de nødvendige oplysninger til at overvåge den løbende læreproces. Med udgangspunkt i de to case-studier vil vi beskrive specifikke perspektiver og siden fortsætte med mere generelle betragtninger om kollaborativ e-læring.

\section{Vægtede perspektiver - intensitetsrelationer}

Da den overvældende mængde af indlæg fra de studerende på MIL gør det næsten umuligt at finde ud af, om pædagogikken i de respektive moduler har resulteret i videndeling og samarbejde, foreslår vi en analyse, som vi kalder for : ”Hvem taler med hvem?” Alle indlæg i de offentlige M1 og M2 diskussionsfora, der besvarede andre indlæg, tælles op, med undtagelse af de indledende indlæg på hver tråd, da de ikke er besvarelser. Svar på indlæg fra ens egen gruppe kalder vi for selvkommunikation. Selv om alle grupperne deltager i indbyrdes kommunikation, viser det sig, at en stor del af indlæggene hører under selvkommunikation. Fem grupper (1, 6, 7, 8 og 10) kommunikerer således mest med deres egen gruppe (se tabel 4). 


\begin{tabular}{|c|c|c|c|c|c|c|c|c|c|c|}
\hline Mfsender & $\mathbf{1}$ & $\mathbf{2}$ & $\mathbf{3}$ & $\mathbf{4}$ & $\mathbf{5}$ & $\mathbf{6}$ & $\mathbf{7}$ & $\mathbf{8}$ & $\mathbf{9}$ & $\mathbf{1 0}$ \\
\hline $\mathbf{1}$ & 27 & 14 & 12 & 12 & 6 & 9 & 17 & 9 & 4 & 17 \\
\hline $\mathbf{2}$ & 10 & 13 & 17 & 16 & 1 & 20 & 14 & 11 & 1 & 26 \\
\hline $\mathbf{3}$ & 12 & 9 & 17 & 8 & 14 & 9 & 19 & 7 & 5 & 15 \\
\hline $\mathbf{4}$ & 8 & 7 & 11 & 9 & 3 & 28 & 4 & 7 & 2 & 12 \\
\hline $\mathbf{5}$ & 6 & 6 & 6 & 4 & 12 & 14 & 7 & 4 & 3 & 12 \\
\hline $\mathbf{6}$ & 11 & 19 & 13 & 26 & 11 & 46 & 14 & 14 & 5 & 35 \\
\hline $\mathbf{7}$ & 12 & 10 & 13 & 8 & 13 & 16 & 42 & 21 & 11 & 37 \\
\hline $\mathbf{8}$ & 11 & 11 & 10 & 6 & 0 & 12 & 16 & 79 & 10 & 21 \\
\hline $\mathbf{9}$ & 24 & 4 & 2 & 3 & 2 & 4 & 14 & 12 & 11 & 17 \\
\hline $\mathbf{1 0}$ & 12 & 23 & 14 & 14 & 18 & 23 & 39 & 24 & 7 & 69 \\
\hline \multicolumn{2}{c}{ sum } \\
$\%$ & 133 & 116 & 115 & 106 & 80 & 181 & 186 & 188 & 59 & 261 \\
\cline { 2 - 10 } selvkom & 20 & 11 & 15 & 8 & 15 & 25 & 23 & 42 & 19 & 26 \\
\cline { 2 - 10 }
\end{tabular}

Tabel 4. Hvem taler med hvem? I offentlige diskussionsfora på MIL i første semester.

(Gennemsnitlig modtager hver gruppe 14 indlag. Tabellen viser stor spredning i kommunikationen mellem grupperne).

Et andet vægtet perspektiv, der yderligere kan belyse den sociale konstruktion i MIL og lignende uddannelser, er fordelingen af indlæg mellem de offentlige og private gruppers diskussionsfora. Denne fordeling giver et indtryk af det første semester i 2002, som understreger, at kommunikationen hovedsagelig foregik internt i grupperne og ikke i det offentlige rum mellem grupperne.

Tabel 5 viser, at aktiviteten er høj i det offentlige M1 diskussionsforum og de private M2 diskussionsfora i modsætning til de private M1 diskussionsfora og det offentlige M2 forum, hvor aktiviteten er lav. Dette vægtede perspektiv afspejler modulernes læringsmålsætning og vurderingskriterier. Selvom tabellen viser, at det kollaborativt designede M1 opnår både et kollaborativt kommunikationsmønster og videndeling, viser modulet også en tendens til selvkommunikation (tabel 5). Det offentlige M2 forum indeholder selvkommunikation og de private M1 og M2 fora er pr. definition selvkommunikative. Det eneste forum hvor der ikke udelukkende foregår selvkommunikation, er derfor det fælles M1 forum. Alt i alt er selvkommunikation den dominerende kommunikationsform i semestret samlet set, og det stiller spørgsmålstegn ved, om man har opnået MIL's overordnede læringsmålsætning om åben videndeling gennem samarbejde, især fordi videndeling mellem grupperne kun kan foregå i de offentlige fora.

\begin{tabular}{|l|c|c|c|c|c|}
\hline Gruppe $\mathbf{n r}$. & $\mathbf{1}$ & $\mathbf{6}$ & $\mathbf{7}$ & $\mathbf{8}$ & $\mathbf{9}$ \\
\hline M1 offentlige & 159 & 265 & 262 & 255 & 82 \\
\hline M1 private & 85 & 139 & 8 & 350 & 0 \\
\hline M1 Total & $\mathbf{2 4 4}$ & $\mathbf{4 0 4}$ & $\mathbf{2 5 4}$ & $\mathbf{6 0 5}$ & $\mathbf{8 2}$ \\
\hline M2 offentlige & 40 & 35 & 52 & 31 & 17 \\
\hline M2 private & 161 & 455 & 263 & 982 & 263 \\
\hline M2 Total & $\mathbf{2 0 1}$ & $\mathbf{4 9 0}$ & $\mathbf{3 1 5}$ & $\mathbf{1 0 1 3}$ & $\mathbf{2 5 3}$ \\
\hline
\end{tabular}

Tabel 5. Indlag i offentlige og gruppe diskussionsfora i M1 og M2. (Kun grupper hvor adgang til private diskussionsfora var givet er optalt i tabellen)

Betyder mønstret i de to forskellige vægtede perspektiver, at der foregår begrænset videndeling? Betyder det, at pædagogikken i henholdsvis M1 og M2 i forening med vurderingskrite- 
rierne faktisk fører til en anden socialiseringsproces, end det var hensigten? Betyder mønstret, at der foregår videndeling, som underviserne bare ikke har indblik i? Perspektiverne giver ikke svar på disse spørgsmål, men de bidrager til, at underviserne kan udforske konteksten og afdække overordnede mønstre og tendenser samt disses intensitet. Og opmærksom iagttagelse af processerne er det første skridt til proaktion.

\section{Dynamiske perspektiver - tids- og annotationsrelationer}

Indlæg i store mængder gør sig også gældende i case-læring. Her er undervisningsaktiviteten ikke primært dialog mellem de studerende, men kollaborativ annotering af case-indholdet og progressionen i annoteringsprocessen. Inspiration til underviserværktøjer, der kan give indsigt i de studerendes læreproces, hentes fra softwareværktøjer til kvalitative analyser, da nogle af disse giver mulighed for dynamiske 'netviews'. Netview er en grafisk illustration af de koder og optegnelser, der er hæftet til et materiale. Netview er et udtryk, som software-applikationen ATLAS.ti bruger (Atlas.ti 2004). Vi foreslår, at lignende faciliteter i CaseMaker giver et visuelt perspektiv af antallet og placering af links mellem nøgleord, kommentarer og materiale. Dvs. brugeren kan interagere med elementerne ved brug af drag n' drop for at se: hvilket materiale viser sig at være det vigtigste? Modsiger nøgleordene hinanden? Er gruppen enig i fortolkningerne? osv., hvilket er med til at styrke en begrundet argumentation og fortolkningsproces. Men det styrker også underviserens overblik over de emner og teorier, som gruppen prioriterer, at underviseren kan følge med i, hvordan gruppen kommenterer og arbejder sammen om annotering af materialet i casen (Figur 1).

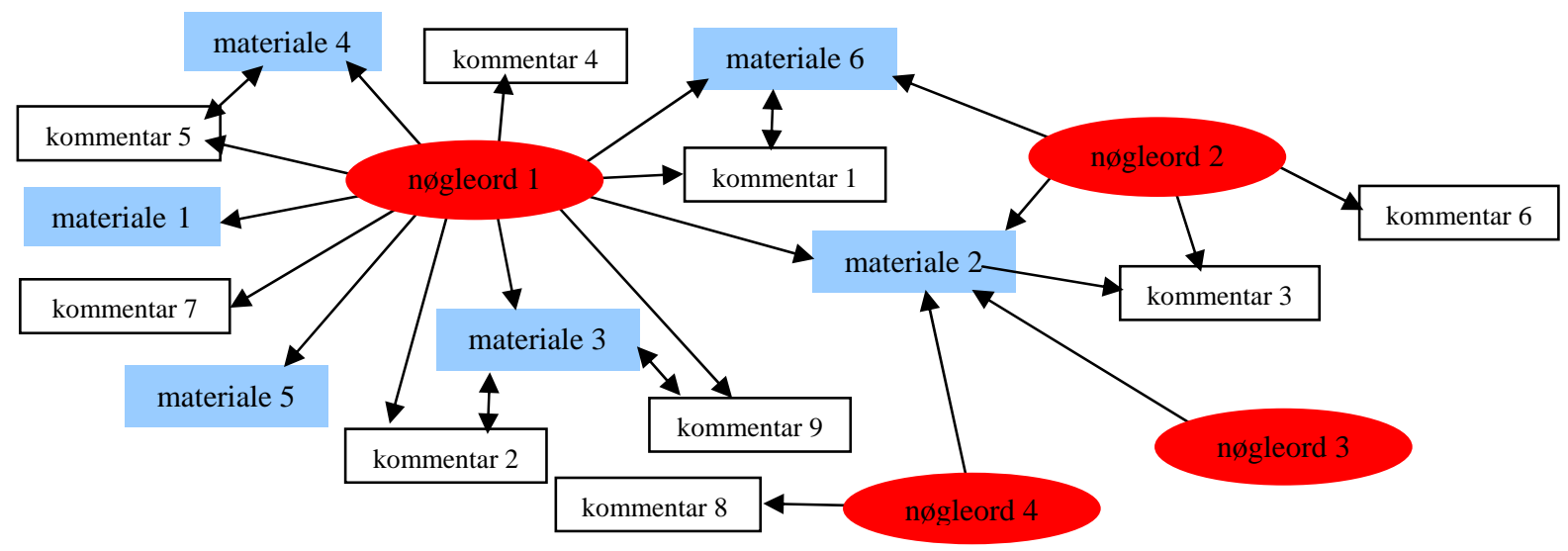

Figur 1. Forslag til et dynamisk perspektiv på notater (Inspireret af ATLAS.ti funktionaliteter)

Som oftest vil underviseren blive konfronteret med mange annoteringer og cases, der strækker sig over en længere periode. Derfor vil det stadig være vanskeligt for underviseren at undersøge den løbende læreproces. I case-læring lever og dør nøgleord og kommentarer. Tidsfaktoren og den måde, annotationer udvikler sig på, bliver således vigtige elementer. Hvis coachunderviseren kan få et overblik over, hvordan annotationer har udviklet sig, er det muligt at proagere, når tendenser i case analysen eller gruppesamarbejdet tager en uheldig eller ufordelagtig drejning. Coach-underviseren kunne proagere ved at facilitere en bestemt gruppes samarbejdsform eller ved at gøre de studerende opmærksom på andre modeller/teorier fra kurset, og derved anspore til dialog om fortolkningen og anvendelse af teorierne i praksis.

Idéen med dette perspektiv er at illustrere annotationer over tid som en animation, der styres af brugeren (i figur 2 kan brugeren interagere med en "slider” (rulleskakt)). På grund af det store antal annoteringer giver den animerede grafiske oversigt en bedre fremstilling af, hvor og hvornår større forandringer dukker op og udvikler sig, end en numerisk grænseflade ville. Eksemplet i figur 2 viser en mulig case-analyses livscyklus. I eksemplet begynder processen først som en temmelig tynd og luftig analyse, hvorpå den nærmest eksploderer i aktivitet - 
måske fordi underviseren har introduceret en speciel model - for til sidst at udkrystallisere sig i de prioriterede nøgleord og den samlede fortolkning.

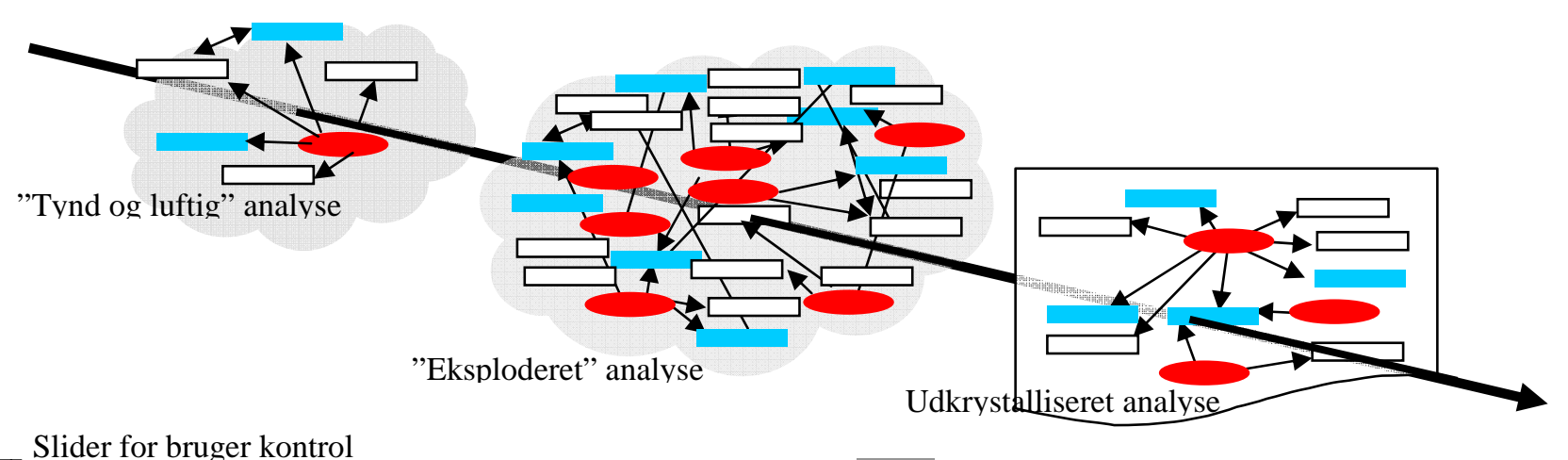

Figur 2: Forslag til et dynamisk animeret perspektiv på annotationer over tid.

\section{Generelle betragtninger}

De ovenstående eksempler peger på mulige anvendelser af vægtede og dynamiske relationer i kollaborativ læring, især case-baserede e-læringsaktiviteter samt netbaserde masteruddannelser baseret på konstruktivistisk pædagogik. Det kunne også være interessant at undersøge perspektiverne på simultane, spatiale og kronologiske relationer eller typologier baseret på elementernes forskellige egenskaber. Forskellige udgaver af kollaborativ pædagogisk praksis vil sandsynligvis udvise analoge forhindringer i forhold til, hvorvidt undervisere kan danne sig et overblik over de fremspirende processer. Denne hypotese definerer et yderligere forskningsområde. Imidlertid vil vi, med det formål at fremme undervisernes mulighed for at agere proaktivt, her foreslå en række relationer, vi finder det vigtigt at udforske og visualisere:

Vægtede relationer

Dynamiske relationer

Annoterede relationer

$$
\begin{aligned}
& =\quad \text { Aktivitetens intensitet i enten tid eller rum } \\
& =\quad \text { Indbyrdes relation og forandring i tid eller rum } \\
& =\quad \text { Brugerdefinerede og tilknyttede relationer samt deres } \\
& \text { indbyrdes forbindelser }
\end{aligned}
$$

Et eksempel på typologi kombineret med vægtede relationer kunne være en tilgang, der viser en typologisk fordeling baseret på konferenceindlægs placering i kommunikationstråden. Herved kan en underviser få et overblik over, hvordan individuelle studerendes indlæg fordeler sig - jævnt eller ensidigt ved begyndelsen eller enden af tråden, inden for tråden eller som udgangspunkt for en eller flere besvarelser. Figur 3 viser en kombination af spatiale og vægtede tilgange med udgangspunkt i Social Network Theory (Wasserman \& Faust 1994). I dette eksempel (som er konstrueret), vil vi vise, hvordan et samlet billede af kommunikationsstrømmen mellem fire grupper kan visualiseres, inklusiv de første mulige fortolkninger. Overblik af denne type kunne inspirere en proaktiv underviser til at kommunikere med grupperne og på denne baggrund beslutte, om deltagerne har behov for at blive coachet og muligvis blive introduceret til andre kommunikationsmønstre.

De foreslåede proaktive underviserværktøjer siger ikke noget om, hvorvidt den resulterende intensitet af selvkommunikationsmønstre eller mønstret af annoteringer over tid er ønskelig set fra underviserens synspunkt. Det afhænger udelukkende af læreprocessen. Da ethvert kursus er designet og planlagt i overensstemmelse med et fagligt indhold og læringsmål, har underviseren som designer altid en idé om og erfaring med, hvad der forventes og er ønskeligt. En vigtig forudsætning for at kunne bruge sådanne værktøjer er derfor, at underviserne gør sig deres forventninger til et kursusforløb eksplicit, mens de planlægger. Det vil gøre dem i stand til at fundere og reflektere over de mønstre, som værktøjerne kan afsløre. Dermed får undervi- 
serne mulighed for at reflektere over hvorvidt, den løbende proces er i overensstemmelse med eller afviger fra de oprindelige forventninger.

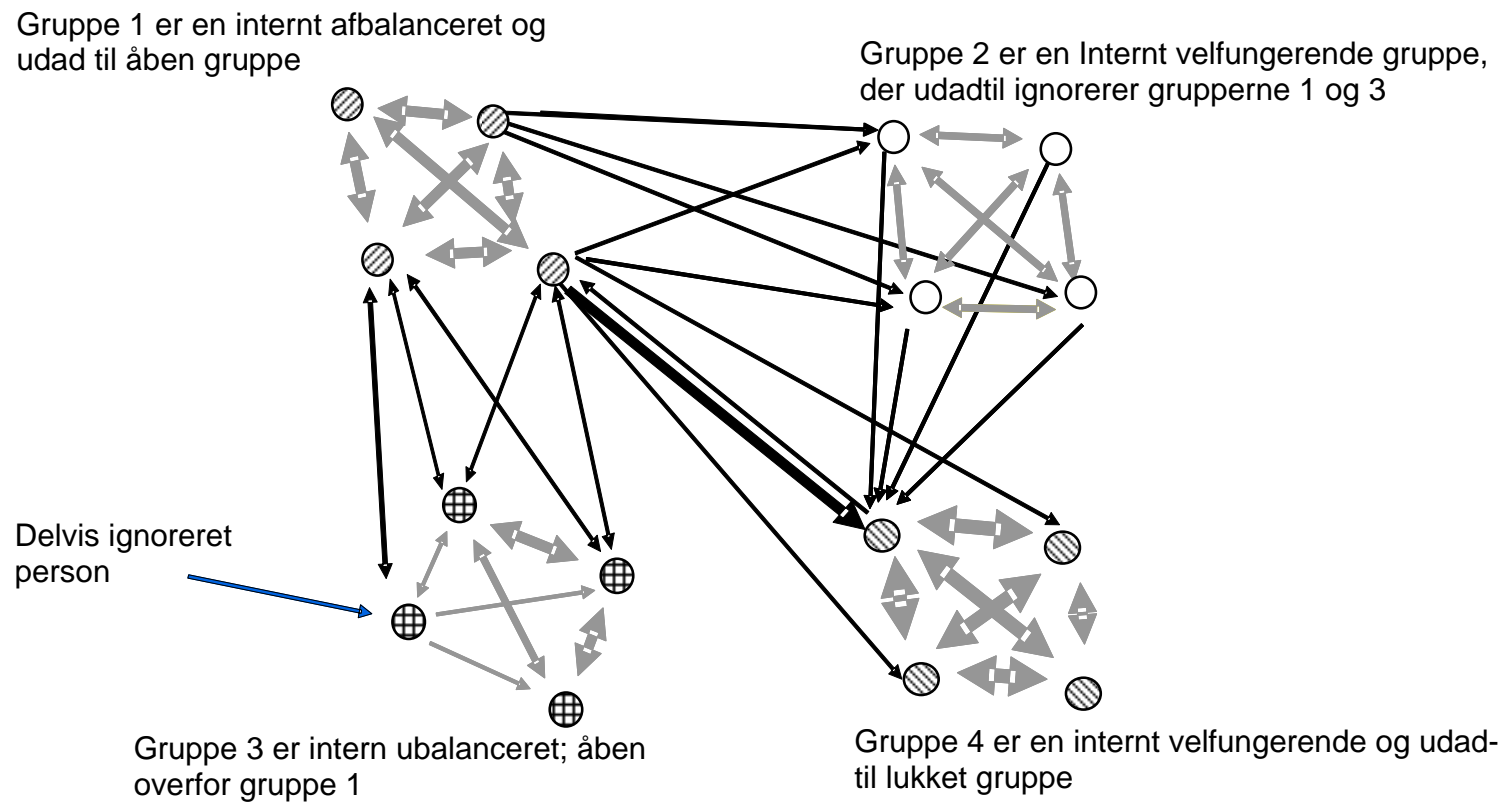

I figuren symboliserer cirklerne de enkelte gruppemedlemme i de 4 grupper. De grå viser gruppeintern kommunikation. De sorte pile viser kommunikation mellem grupper. Pilenes tykkelse illustrerer relativt mængden af henvendelser mellem personerne

Figur 3: Forslag til spatiale og vagtede tilgange i et grafisk layout. Eksemplet er fiktivt.

\section{Konklusion - afsluttende bemærkninger}

Vi mener, at proaktive underviserværktøjer kan give os indsigt i de kollaborative og kommunikative mønstrer, der opstår under udviklingen af praksisfællesskaber, i modsætning til automatiserede værktøjer der fortæller underviserne, hvordan de skal agere i overensstemmelse med forskellige typer af mønstre. Kollaborative læreprocesser som i disse case-studier kræver planlægning, men de kan ikke forudsiges. Det betyder, at nødvendige proaktive beslutninger og handlinger, for en coach-underviser altid vil være kontekstuelle og situerede.

Pointen er, at vi i dag ikke kan vælge at proagere på svage tendenser, da nuværende LMS ingen metoder har til at indfange dem. Selv når underviserne tager aktivt del og medierer i online-diskussioner, kan de ikke afsløre selvkommunikation eller udelukkelse af bestemte studerende, førend sådanne mønstre fremstår iøjnefaldende som et dominerende adfærdsmønster. Hvis LMS giver undervisere mulighed for at proagere ved hjælp af proaktive underviserværktøjer, så er det underviserens valg, om han eller hun ønsker at gribe proaktivt ind som coachunderviser. I dag har underviseren ikke dette valg.

Det er altså væsentligt, som e-lærings underviser, der anvender kollaborative pædagogikker, at overveje, hvordan indblik i den igangværende læringsproces opnås for at skabe rum for proaktiv handlen og coaching. På nuværende tidspunkt kan et sådant indblik og overblik kun skabes ved manuelt at sortere de mange indlæg, - f. eks. ud fra filtreringer svarende til de perspektiver vi præsenterer i denne artikel. Derfor mener vi, der ligger en fremtidig opgave, i at LMS’er bør designes med proaktive underviserværktøjer for øje.

Som en afsluttende bemærkning vil vi påpege, at implementering af proaktive værktøjer også vil give de studerende værktøjer, som de kan anvende til metarefleksion i forbindelse med deres egen løbende læreproces, og dermed supplere brugen af portfolio. Det er imidlertid et andet perspektiv, som vi bevidst ikke har berørt nærmere i denne artikel. 


\section{Efterskrift}

Denne artikel er en viderebearbejdning af vores forskningsarbejde og af konferencebidraget: "Pro-active Teaching Tools" fra European Conference on E-Learning. (Orngreen \& Levinsen 2004). CaseMaker er finansieret af CBS E-læringsfond, og udvikles i et tæt samarbejde med CBS Learning Lab med Rikke Ørngreen som projektleder. Vi takker CBS Learning Labs medarbejdere. MIL case-studiet er en del af Karin Levinsens Ph.D.-arbejde, og vi takker studerende, lærerne og andre medarbejdere for deres hjælpsomhed og for at dele deres erfaringer.

\section{Litteratur}

Ackoff, Russell L. En ny fremtid formes. Nyt Nordisk Forlag. 1976

Argyris, C. "Some Limitations of the Case Method: Experiences in a Management Development Program". I Academy of Management review, Vol. 5, no. 2. 1980. 291-298.

Atlas.ti 2004, et kvalitativt dataanalyse software værktøj, for mere information se: $<$ http://www.atlasti.de>. (Checket den 31/7 2004).

Claroline 2004: Claroline : Open Source e-Learning, <http://www.claroline.net>. (Checket 23/7 2004).

Dirckinck-Holmfeld, L.’Designing Virtual Learning Environments Based on Problem Orientated Pedagogy". I Dirckinck-Holmfeld \& Fibiger (eds.): Learning in Virtual Environments. Samfundslitteratur. 2002. 31 - 54.

Fjuk. A. and Ludvigsen, S. "The Complexity of Distributed Collaborative Learning: Unit of Analysis”. I Proceedings of Euro-CSCL 2001. <http://www.mmi.unimaas.nl/euro$\mathrm{cscl} /$ presentations.htm $>$. (Checket 31/7 2004).

Heath, J. Teaching and writing Case-studies - a practical guide. The European Case Clearing House. Cranfield University, Bedford, UK. 1998.

Hildebrandt, S. ”Der skal skæres til der er friskt blod”, Dagbladet Børsen, 12. december 1997.

Laurillard, D.: Rethinking University Teaching. A conversational framework for the effective use of learning technologies. Ruthledge Falmer. 2002.

Levinsen, K. "Management Tools for online teachers - a Proactive Approach to E-learning", submitted to The eighth IFIP World Conference on Computers in Education (WCCE 2005), 4 - 7 July 2005, University of Stellenbosch, Cape Town South Africa. 2005.

Levinsen, K. "Klædt på som online-underviser - kommunikation som barriere for netstøttet undervisning”. Tidsskrift for Universiteternes efter- og videreuddannelse nr. 1, 2003. $<$ http://www.unev.dk/view.aspx?artikel_id=259>, (Checket 31/7 2004).

Levinsen, K. ”Kan man finde de studerendes forudsætninger i et virtuelt miljø?”. I M. Georgsen and J. Bennedsen (eds): Fleksibel laring og undervisning - erfaringer, konsekvenser og muligheder med ikt. Aalborg Universitetsforlag. 2004. 85-106.

Levinsen, K. \& R. Orngreen. "Locating Students' Competencies - A Prerequisite for Collaboration”. I Proceedings in 2nd European Conference on e-Learning. Glasgow Caledonian University, Glasgow, Scotland. 2003. 261-266.

Mauffette-Leenders, L. A; Erskine, J. A. \& Leenders, M. R. Learning with cases. Richard Ivey School of Business, the University of Western Ontario, Canada. 1997.

MIL Modulkatalog. 1. års forløb og 2. års forløb i Modulkatalog. Udgivet af Aalborg Universitet, Master i IKT og Læring. 2002.

Murphy, K. L., Epps, M. L., \& Harvell, T. J. "Proaction vs. Reaction: Interaction and Group Dynamics in Telecommunications Courses". The Texas Technology Connection: Journal of the Texas Association for Educational Technology Proceedings Edition, 6(1). 1999. 32-34.

Orngreen, R.: Multimedia Teaching Cases, Ph.D.-series 27.2002, Samfundslitteratur, Frederiksberg. 2002

Orngreen, R. “CaseMaker: “An Environment for Case-based e-Learning”. I The Electronic Journal on e-Learning, Volume 2 Issue 1. February 2004. 167-180. 
Orngren, R. \& Levinsen K.: "Proactive Teacher Tools - Enabling Teachers to Proact During e-learning Activities”. I (ed.) Dan Remenyi, 3 European Conference on e-learning, Paris nov. 2004. 569 - 579.

Orngreen, R., Nielsen, J. \& Levinsen, K. “Client Centred Design”, Informatics workingpaperseries, 13/2004. 11 pages. <http://www.inf.cbs.dk/departments/inf/workingpapers/index.shtml>, (Checket 17/11 2004).

Reffay, C. \& Chanier, T. "How Social Network Analysis can help to measure cohesion in collaborative distance learning”. I Proceeding of Computer Supported Collaborative Learning conference. Bergen. 2003. 343-352.

Reigeluth C. M. (ed.). Instructional-Design Theories and Models. Lawrence Erlbaum Associates. 1999.

Salmon, G. E-tivities. The key to active online learning. Kogan Page. 2002.

Sorensen, E. K. "A Challenge in E. Orchestrating the Symphony of Collaborative ELearning”. I The International Journal of Innovations in Higher Education (IJIHE). 2003.

Sorensen, E. K. and Takle. G. S. "Learning through Discussion and Dialogue in Computer Supported Collaborative Networks.” I Society for Information Technology and Teacher Education International Conference Vol. 2003, Issue. 1, 2003. 2504-2510.

Sorensen, E.K. "Designing for Collaborative Knowledge Building in Online Communities of Practice". I Hansson, H. (ed.): Eight Contributions on Quality and Flexible Learning. Report 1. Swedish Agency for Distance Education. 2002. <http://www.myndigheten.netuniversity.se/download/812/x/quality.pdf> . (Checket 20/7 2004).

Stelter, R. Coaching - læring og udvikling, Psykologisk Forlag, 2002

Wasserman S. and Faust K. Social Network Analysis: Methods and Applications. Cambridge University Press. New York, 1994.

Wenger, E. Communities of Practice. Learning, Meaning, and Identity. Cambridge University Press. 1998.

Williams, S. "Putting Case based instruction into context: examples from legal and medical education". I The Journal of the Learning Sciences, 2(4), 1992. 367-427 